\title{
Double Jeopardy for Misconduct and Increase of Sanction at the Appeal Court: Unfair Labour Practice Revisited
}

\author{
Tshikovhi RH
}

Kola 0 Odeku

Faculty of Management and Law, School of Law,University of Limpopo, South Africa

Email:kooacademics@gmail.com

Doi:10.5901/mjss.2013.v4n14p813

\begin{abstract}
This article examines whether the employer can charge an employee twice for the same misconduct in labour law in view of Section 188(1)(a (b) of the Labour Relations Act 66 of 1995, (herein referred to as the LRA) which provides that the dismissal is unfair if the employer fails to prove that the reason for the dismissal is fair and was effected in accordance with a fair procedure. The article highlights that the principle of double jeopardy principle applies to labour law and enumerates how the employee can invoke it to justify that the conduct of the employer amounts to unfair labour practice. In discussing this principle, the article relies heavily on the judgements and pronouncements of the South African courts. The articles analyses the circumstances under which an employee can be charged twice for the same misconduct and considers whether it is appropriate and fair to increase the sanction on appeal or by a sanction imposed by the chairperson of the disciplinary hearing. The article also highlights situations where it is fair to the employer to hold second hearing. This is against the backdrop that fairness does not only apply to the employees alone but also to the employer in order for the hearing to be determined in a fair manner to both parties involved.
\end{abstract}

Keywords: Double jeopardy, Disciplinary hearing, Misconducts, Fairness, Appeals

\section{Introduction}

The principle of doubly jeopardy in labour law and labour relations simply explains that no employee or persons in employment shall be put in jeopardy twice and be made to answer for a misconduct already sanctioned for in the workplace.

This is against the backdrop of section 23(1) of the Constitution of the Republic of South Africa Act 108 of 1996 which protects everyone's right to fair labour practice (Goldstone 1997). The LRA succinctly provides that employees have the right not to be unfairly dismissed and the right not to be subjected to unfair labour practices (Workman-Davies, 2007). Undoubtedly, an employee who is put on trial for the same misconduct is considered to be unfairly treated and if dismissed, such dismissal is tantamount to an unfair dismissal constituting an unfair labour practice (Okpaluba 1999). The main rationale for the application of the double jeopardy principle in labour disputes is to ensure that a misconduct hearing is finalised and that the decision reached becomes binding on all the parties (Roberts 2002). A very pertinent issue to the application of double jeopardy principle is to consider whether on appeal, the appellate court can increase the sanction already imposed by the panel and the chairman of the first instant disciplinary hearing (Brown and Lee 1999). This issue and other related doubly jeopardy issues shall be articulated and explained by relying on judicial decisions, legislation and scholarly works in order to find solutions to them.

\section{Objective of the Study}

The objective of the article is it to examine whether the employer can persuade the appellate body to increase sanction that has been imposed already by the chairperson of the first instant disciplinary hearing. The article will also consider the consequences of requesting for increase in sanctions and argues that this is tantamount to being sanctioned twice for the same offence thereby against the principle of double jeopardy in labour law. Another objective linked to the first objective is the consideration of when it will be fair for the employer to hold second hearing. For instance, if evidence that was not made available in the first hearing emerges thereafter, the employee cannot stop the employer to tender such 
evidence in the second hearing in so far as it will assist in clarifying the issues and employee is allowed to cross examine accordingly. In this situation, then it is fair to allow the second hearing.

\section{Motivation and Significance of the Study}

The article showcases how the principle of double jeopardy contributes to the development of labour law by ensuring that cases that have been finalised are not re-opened.

This article will benefit labour law practitioners including employers, employees, organised labours, attorneys, presiding officers and others as it shows how the principle of double jeopardy practically applies in labour and how an employee can invoke it in order to seek redress and remedy for unfair sanctions. Overarching benefits of this work is how it will have impact on disputes and reduce unnecessary litigations, reduce the amount of time and costs spent on litigations and decongests the courts' list.

\section{Literature Review}

The crucial question on whether the employer's decision to increase the sanction for misconduct was fair or not was considered in the most celebrated case of Greater Letaba Local Municipality v Mankgabe NO \& others. The employer instituted disciplinary proceedings against the employee after the latter had been involved in an accident whilst driving the employer's motor vehicle without the necessary authorisation, which resulted in the vehicle being written off. The employee was found guilty and the chairperson imposed a sanction of a final written warning and ten days suspension without pay. The Executive Committee of the employer approved the findings but dismissed the employee. The commissioner ruled that the dismissal was unfair and reinstated the employee. On review, the Labour Court per Rampai AJ held that the employer's sanction was procedurally unfair since the employee was not afforded an opportunity to be heard before the sanction was changed. The court further held that the dismissal was substantively fair but procedurally unfair and ordered two months compensation to be paid to the employee.

The principle of audi alteram partem rule (which means both parties should be given the right to be heard) should have been followed by the Executive Committee and the employee should have been given an opportunity to give reasons why the sanction should not be changed. Another important aspect of the Greater Letaba's case is that it establishes that substantive fairness outweighs procedural fairness. This means that an employee whose dismissal has been procedurally unfair shall not be reinstated but compensation shall suffice (Stewart, 1995). The fact that the sanction was effected without the employee's input contravenes section 186(1) (b) of the LRA which provides that the employer must prove that the employee's dismissal was effected in accordance with a fair procedure. It is grossly unfair to have the chairperson of a disciplinary hearing pronouncing the sanction after listening to the employer and employee's mitigation factors and willy-nilly changed the sanction without the employee given the opportunity to be heard.

\section{Can an Employee be Put in Jeopardy Twice for the Same Misconduct?}

The question whether the employer can legitimately charge an employee twice for the same misconduct has been controversial in the employment law. There are a vast number of case laws which provide guiding principles on the application of the double jeopardy principle. Generally, if an employee has been acquitted at the disciplinary inquiry, or if the chairperson has imposed a penalty less severe than dismissal, the employee cannot be subjected to the second inquiry in respect of the same misconduct. A dismissal in such circumstances would invariably be regarded to be unfair based (Grogan, 2008).

The Labour Court's remarks in FAWU Obo Kapesi \& others v Premier Food Ltd t/a Blue Ribbon Salt River (2010) 31 ILJ 1654 (LC) are worth noting and imperative for purposes of these discussions. The court held that "A disciplinary hearing is not criminal trial. It is also not a civil trial. A disciplinary hearing is an opportunity afforded to the employee to state a case in response to the charges levelled against him or her by the employer." As pointed out earlier, the criminal law system is to a certain extent different from the labour law. The important principle in labour law is that an employee should be afforded an opportunity to state his case and answer to the charges in the disciplinary hearing (Abrams and Dennis 1985).

The case of BMW SA Ltd v Van Der Walt (2000) 21 ILJ 113 (LAC), provided some important principles on the double jeopardy principle. In that case, the appellant (BMW) declared a certain wheel alignment equipment to be redundant and having nil value. The respondent employee discovered that the scrap value was actually R15 000-00. The 
employee arranged that his fictitious company should purchase the scrap metal. The employee received a repairing invoice of R11 000-00 and also an offer to purchase the scrap metal at a cost of R50 000-00. The employer instituted disciplinary proceedings against the employee. On or about January 1995, the disciplinary inquiry found that the employee had not committed misconduct and, as a result, no sanction was imposed. In February 1995, the employee was charged with a new charge of misrepresentation in that the employee made certain misrepresentations when the wheel alignment was removed from the employer's premises. The employee was dismissed. Conradie JA with Nicholson JA concurring held that:

\begin{abstract}
"whether or not a second disciplinary inquiry may be opened against an employee would, I consider, depend upon whether it is, in all the circumstances, fair to do so." The court further held that "the attempted sale of the equipment took a different colour and demonstrated fraudulent intent far beyond making a false representation in order to move the goods out of the employers' premises."
\end{abstract}

The court further considered and applied the dicta in Amalgamated Engineering of SA \& others v Calton Paper of SA (Pty) Ltd (1988) 9 ILJ 588 (IC) that:

\footnotetext{
"...it is unnecessary to ask oneself whether the principle of autrefois acquit or res judicata ought to be imported into labour law as they are public policy rules. The advantage of finality in criminal and civil proceedings is thought to outweigh the harm which may be caused on individual cases by the application of the rule. In labour law, fairness and fairness alone is the yardstick."
}

The majority of the Labour Appeal court found that the second hearing was justified and fair. The minority's view was that there is no evidence that the first hearing was contrary to the disciplinary code. The minority per Zondo AJP held that the appellant employer was to be blamed for not properly conducting the investigation prior to the first hearing and thus it was unfair to subject the respondent employee to a second hearing. Zondo AJP went further and held that "In my view, the new information on the basis on which the appellant sought to justify its conduct in subjecting the respondent to more than one disciplinary inquiry does not constitute exceptional circumstances" Amalgamated Engineering of SA \& others v Calton Paper of SA (Pty) Ltd (1988) 9 ILJ 588 (IC), paragraph 36. The judgment of Zondo AJP for the minority is an acknowledgment and confirmation that there are circumstances under which an employee may be subjected to a second hearing on the same facts.

The basic and underlying principle of fairness was applied in the above case. This means that the presiding chairperson has to strike the balance between the interests of the parties on the facts which are placed before him/her. The authors subscribed to the findings and reasons thereof in the BMW's case. If it so appears that it is unfair and prejudicial for the employer to charge an employee for the second time, the authors are of the view that the double jeopardy principle should apply and disagree with the reasoning of the minority. The minority held that the appellant employer did not prove exceptional circumstances to subject the respondent to a second inquiry. However, the appellant brought evidence relating to the attempted sale of the scrap metal, which constitutes a fair reason for holding second hearing as this evidence was not available during the first hearing. Moreover, fairness does not only apply to employees alone but also to the employer and this means that the hearing should have been determined in a fair manner to both parties involved.

As in NUMSA v Vetsak Co-Operative LTD 1996(4) SA 577 (A) at paragraph 589, Smalberger JA held that:

\footnotetext{
"...fairness comprehends that regard must not only be to the position and interests of the worker, but also those of the employer in order to make a balanced and equitable assessment. The court went further and held that in judging fairness a court must apply a moral or value judgment to established facts and circumstances. It would, be very much unfair if employers are not allowed to charge an employee on the new evidence although emanating from the same facts."
}

Both the majority and the minority in BMW's case have placed a very crucial limitation to the abuse of powers by placing fairness and exceptional circumstances respectively to determine whether an employee can be charged twice on the same facts. It is also imperative that the fairness should be applied to both the employer and the employee.

The case of Bramford v Metrorail Services (Durban) \& another (2003) 24 ILJ 2269 (LAC) further demonstrates the correct labour law position with regard to the double jeopardy principle. In this case, the appellant employee who had 21 years in service was charged and subsequently dismissed for making eight fraudulent petty cash claims totalling R 83400 for items such as tea, sugar, milk etc. The appellant employee also forged a signature of his manager. Following a 
meeting with his line manager regarding the allegations, the line manager gave the employee a dressing down and issued a formal warning. The regional management conducted a formal audit. After the audit, the employee was subjected to a disciplinary hearing and was later dismissed on 20 October 2000. The arbitrator found that the second hearing was unfair and ordered reinstatement, but the Labour Court reviewed and set aside the award.

The Labour Appeal Court per Jafta AJA with Nicholson JA concurring held that the current legal position as pronounced in Van der Walt BMW SA Ltd v Van Der Walt (2000) 21 ILJ 113 (LAC) is that a second inquiry would be justified if it would be fair to constitute it. The court further held that "there was only one hearing in the present matter but accepted that the appellant employee was subjected to two successive punishments and the employer is entitled to hold a second disciplinary inquiry. Further that the arbitrator has failed on the facts to apply them and consider issues placed before him". At paragraph 22, Jafta AJA held that:

\begin{abstract}
"...the arbitrator was married to the idea that since it was competent for Palmer (line manager) to issue a written warning, the employer was bound by the latter's action irrespective of whether Palmer's decision to issue a warning was correct or not and despite possibility of Palmer having been influenced by ulterior motives."
\end{abstract}

The Labour Appeal Court concluded by holding that the employer was denied the opportunity of having the issue of fairness of dismissal considered in a fair public hearing and by means of applying relevant law. The court upheld the decision of the court a quo and dismissed the appeal with costs.

Although arbitration awards are not necessarily binding, arbitrators have followed the reasoning of the cases of BMW and Bramford in the most recent case of Petusa obo Rootman v Absa (2009) 30 ILJ 2544 (CCMA). In this case, the applicant had been employed by the respondent for about 20 years and served as planner in its private bank division. The applicant invested funds from six clients using non-approved intermediary in 2005 despite memorandum that nonapproved service providers could not be used. The applicant was charged and found guilty of not adhering to bank's policy and was given a final written warning. In 2008, it came to light that investments arranged by the applicant were not secured and that the bank was exposed to a loss of R1.2 million. The applicant was then charged with dishonesty and was dismissed. The commissioner ruled that the charges against the applicant employee in both hearings were similarly phrased. However, the commissioner held that when the bank became aware that it had suffered a significant loss, it must have suspected that the applicant deliberately misled them. The Commissioner concluded that in the circumstances, charging the applicant for the second time on the same facts was not per se unfair. The findings and conclusions of the arbitrator are true reflection of the current employment position that it is not always unfair to subject an employee to two disciplinary hearings or sanctions. The Labour Appeal Court in Country Fair Foods (Pty) Ltd v CCMA \& others (2003) 24 ILJ 355 (LAC) held that the manager's decision to review and set aside the sanction of a final warning to suspend and dismiss the employee was unfair. The only reason given by the court was that there was no provision in the disciplinary code for interference with a penalty imposed after a properly constituted disciplinary inquiry.

The question whether an employee is fairly subjected to a second hearing may depend on some of the following factors inter alia as follows which comes from the case law:

a) For the sake of consistency;

b) The gravity of the employee's offence;

c) The period elapsed between the first and the second hearing;

d) The circumstances and availability of new and relevant evidence after the first hearing.

e) The chairperson of the first hearing's failed to properly apply his mind to facts due to biased, unduly influenced views or acted mala fide (BMW v Van der Walt (2000) 21 ILJ 113 (LAC).

In the event that the employer decides to subject an employee to a second hearing, such decision should be made timeously or within reasonable time (van Jaarsveld 2007). The question of what constitutes reasonable time depends on the circumstances of the case and measured on the reasonable man's test. In Mokoetle v Mudau NO \&others (2009) 30 ILJ 2755 (LC), the applicant employee was charged in 2006 on five counts of misconduct on events which occurred in 2003. The chairperson recommended a final written warning on four charges and a written warning on the fifth charge. The Group Chief Executive Officer of the South African Broadcasting Corporation (SABC) accepted the findings and informed the applicant employee as such. The applicant referred an unfair labour practice dispute to the CCMA claiming that there had been undue delay in instituting disciplinary proceedings. The conciliating Commissioner issued the outcome certificate but the arbitrating Commissioner refused to arbitrate on the ground that the arbitration process will serve no purpose since the employment relationship had been terminated.

The Labour Court held in paragraph $19 \mathrm{G}$ that "A fortiori, the applicant has approached this because of the actual prejudice occasioned by the third respondent's delay in instituting disciplinary proceedings against him, assuming for a 
moment that it is at large to institute such proceedings after previously electing not to do so. (In my view it is not). The prejudice against the applicant is thus manifest." The court went further to order that the "third respondent was precluded on account of its binding election or waiver, from instituting and pursuing disciplinary proceedings against the applicant."

In the case of Bregem v De Kock NO \& others (2006) 27 ILJ 2352 (LC), the applicant was charged after publishing a book on the court battle between the third respondent (employer) and another employee. The chairperson of the disciplinary hearing ruled that the applicant (employee) and the third respondent (employer) should meet to agree on a financial settlement failing which the applicant will be automatically dismissed. On a meeting following the chairperson's ruling, an agreement could not be reached as the applicant wanted five million but the third respondent was offering R150 000-00. The applicant, after this meeting, alleged criminal activities and threatened to report the alleged criminal activities to the authorities. The employer instituted further disciplinary proceedings on allegations of dishonesty and the applicant was found guilty and consequently dismissed. The Arbitrator found that the dismissal was fair. The Labour Court held on paragraph 14 that:

\begin{abstract}
"The effect of the order of the first disciplinary enquiry chairperson was clear and unambiguous in this respect: If the matter could not be resolved financially, the applicant would be automatically dismissed in terms of the charges levelled against him. The matter could not be resolved financially, and, therefore, the applicant was to be dismissed. It was not open for the third respondent to charge the applicant a second time in such circumstances....in that respects his second dismissal was unfair, apart from the fact that the first dismissal was also unfair...."
\end{abstract}

Although, this case did not deal with double jeopardy, however, when one looks at the circumstances leading to the second hearing, it becomes abundantly clear that, in fact, the applicant was subjected to two hearings. The question whether the second hearing was fair can be looked at in the light of the facts of the case. The chairperson of the first hearing ruled that the applicant would be automatically dismissed in the event that no financial settlement was reached. On this basis, the applicant was no longer an employee when the second hearing was instituted. The settlement negotiations were, by their very nature, without prejudice. In any event, the applicant reported the criminal activities to the auditors' that is, PriceWaterhouseCoopers (PWC) and the South African Revenue Services (SARS) and these were surprisingly not disputed during the arbitration. The court's finding in this case is the true reflection of the application of the principle because the chairperson of the first hearing made a determination that the employee would be automatically dismissed in the event that both the employer and the employee could not reach a financial settlement. Technically, at the time when the employee was subjected to the hearing, he was already dismissed. It was only left for the employer to confirm and/ or implement the chairperson's determination.

In the case of Ekhuruleni Metropolitan Municipality v Mashazi NO \& another [2009] 12 BLLR 1198 (LC) paragraph 35-38, the municipality instituted disciplinary proceedings against the employee on allegations of misconduct. The chairperson of the hearing ordered the employee to repay the amounts received from the tenderer. The municipality instituted review proceedings contending that the disciplinary hearing was irregular as the employee was in contact with the chairperson and the sanction was shockingly inappropriate. The court held that the review application was brought in terms of section 158(1)(h) of the Act. It is clear that from the authorities cited above that no other cause of action on which to build a review exists in our law." This conclusion was endorsed in Transman (Pty) Ltd v Dick \& another (2009) 30 ILJ 1565 (SCA) where it was held that there was no need to permit a challenge based on the judicial review in employment dismissals. The application stood to be dismissed. The following cases were also referred to: Kriel v Legal Aid Board SA Kriel v Legal Aid Board [2009] 9 BLLR 854 (SCA) and Makambi v MEC for Education, Eastern Cape [2008] 8 BLLR 711 (SCA).

The court went further and held that the applicant (the municipality) is not left without remedies referring to MEC for Finance, KZN \& another (2009) 30 ILJ 2653 (SCA) and BMW. The applicant should have in the circumstances instituted a second hearing on the grounds that the chairperson did not apply his mind to the facts and the seriousness of the misconduct but imposed an inappropriate sanction.

\title{
6. Can the Employer Increase a Sanction on Appeal?
}

The LRA does not provide for the right to appeal, however most disciplinary codes provide for the right to appeal (SALGBC, 2010). The employee should in terms of the disciplinary code be afforded an opportunity to appeal unless he or she has waived the right to appeal. Waiver can be by means of failing to lodge an appeal or failing and/ or refusal to prosecute an appeal. The general rule is that the presiding officer of the appeal should not have been, in any way, involved in the initial hearing. This also applies even when the appeal takes the form of a hearing de novo (Grogan, 
2008).

In UNISA v Solidarity obo Marshal \& others [2009] 5 BLLR 510 (LC), the respondent employee was found guilty of fraud and was dismissed. The appeal tribunal then altered the sanction to 12 months suspension without pay. The respondent referred a dispute to the CCMA. The commissioner found that the 12 months suspension was not authorised by the disciplinary code and ordered 3 months suspension without pay and a final written warning. In a review, the Labour Court per Moshoana AJ held that it makes no sense that the appeal committee would be guided by the same disciplinary code and procedure that guides the disciplinary committee, particularly when it comes to the issue of sanctions. There seems to be no justification in law for such a disparity which shows evidence of unfairness. If such argument is correct, it simply means that the employee would be saddled with a sanction imposed by the disciplinary committee albeit in excess of its powers. Although the above case does not answer the question whether the appeal tribunal may increase a sanction on appeal, it raised an important and interesting issue which emanated from the relationship between the disciplinary tribunal and the appeal tribunal. The said sanction suggests that it is unfair to increase a sanction on appeal.

The Labour Appeal Court in Nasionale Perkeraad v Terblanche (1999) 20 ILJ 1520 (LAC) held that in labour law context where an appeal amounts to re-hearing, a court should be slow to find that appeal proceedings could not correct a deficiency of the natural justice in the original proceedings. The court noted that in labour law, as opposed to administrative law, a wronged employee has a right to a trial de novo in court or in arbitration proceedings. There is no general rule that employees are entitled to an appeal before they could exercise statutory relief. However, if the employer and the employee have agreed that the latter has the right to appeal, the former may not refuse the employee to exercise such right. The employer may not institute an appeal tribunal in the event that the employee has decided to utilize the statutory bodies created in terms of the LRA.

In Rennies Distribution Services (Pty) Ltd v Biermen NO \& Others [2009] BLLR 685 (LC) the Labour Court gave exceptions to the rule that sanction may not be increased on appeal. The court held "firstly, except where express provision is made for such a power, a chairperson on appeal does not have the necessary power to consider."

It appears that the appeal tribunal may increase the sanction on appeal if permitted by the disciplinary code. On the principle of the Greater Letaba's case, where the employer was found to have had a substantive reason for the dismissal but the procedure was unfair as the employee was not afforded an opportunity for hearing when the employer altered the sanction. The employer may also increase sanction if the employee has been warned and given reasonable opportunity to state his/her case about the possibility that the sanction may be increased.

\section{Conclusion}

The employer may within the parameters of fairness institute a second hearing against the employee on the same facts. It is also imperative to note that fairness does not only apply to the employer when it comes to whether or not to institute a second hearing but the employee as well. The employer may hardly be justified in increasing a sanction on appeal unless the employee has been a party to that effect and was given a reasonable opportunity to show reason(s) why the sanction should not be increased on appeal. The provision of the disciplinary code is important on this aspect. The employer may also not deviate from the sanction imposed by the chairperson of the disciplinary hearing unless the collective agreement and fairness so dictate.

\section{References}

Abrams RI, Dennis R N 1985. Toward a Theory of "Just Cause" in Employee Discipline Cases, Duke Law Review, 1985(3):594-623.

Brown J R, Lee AH 1999. Neutral Assignment of Judges at the Court of Appeals, 78 Texas Law Review,78;1037-1048. Goldstone RJ 1997. The South African Bill of Rights, Texas International Law Journal, 32: 451-459.

Grogan J 2008. Workplace law, Juta, Cape Town, South Africa.

Okpaluba C 1999. Opportunity to State Case in the Law of Unfair Dismissal in Swaziland in the Light of the Developments in South Africa and the United Kingdom, African Journal of International Comparative Law, 11: 392:401.

Roberts P 2002. Double Jeopardy Law Reform: A Criminal Justice Commentary, The Modern Law Review, 65(3): 393-424.

SALGBC 2010. South African Local Government Bargaining Council: Disciplinary Procedure and Code Collective, 2010. From http://www.salgbc.org.zal. (Retrieved May 19, 2013).

Stewart A 1995. And (Industrial) Justice for All - Protecting Workers against Unfair Dismissal, Flinders Journal law Reform 1:85-96.

van Jaarsveld M 2007. Annual Survey of South African Law, Labour Law Journal, 2007: 658-669. Workman-Davies B 2007. Right of Employers to Dismiss Employees in the Context of Business Transfers - An Analysis of the Automatically Unfair Dismissal Provisions of the Labour Relations Act, Industrial Law Journal, 28:2133-2142. 